() А. В. ЧОРНОМИДЗ

ДВН3 “Тернопільський державний медичний університет імені І. Я. Горбачевського”

\title{
Функціональний стан ендотелію судин мікроциркуляторного русла у хворих на гострий панкреатит
}

\author{
A. V. CHORNOMYDZ \\ SHEI "Ternopil State Medical University by I. Ya. Horbachevsky"
}

\section{FUNCTIONAL STATE OF ENDOTHELIUM OF VESSELS OF MICROVASCULAR BED IN PATIENTS WITH AN ACUTE PANCREATITIS}

\begin{abstract}
Досліджено активність ендотелію судин у 60 хворих на гострий панкреатит із застосуванням лазерної доплерівської флоуметрії. Вивчено особливості реагування ендотелію судин на тимчасову оклюзію залежно від тяжкості панкреатиту. В усіх хворих виявлено ознаки ендотеліальної дисфункції. Складено стадійність функціональної недостатності ендотелію судин. При виписуванні хворих на гострий панкреатит виявлено ознаки дисфункції ендотелію, що свідчить про відсутність адекватного медикаментозного впливу на цю ланку патогенезу захворювання.

It was studied the activity of vascular endothelium in 60 patients with an acute pancreatitis, using laser Doppler flowmetry. The features of vascular endothelial response to temporary occlusion, depending on the severity of pancreatitis were studied. In all patients were detected signs of endothelial dysfunction and functional impairment is made staging the vascular endothelium. At discharge, in patients with acute pancreatitis were detected signs of endothelial dysfunction, which indicates a lack of adequate medical impact on this link the pathogenesis of the disease.
\end{abstract}

Постановка проблеми і аналіз останніх досліджень та публікацій. Значне збільшення захворюваності на гострий панкреатит зумовлює актуальність даної проблеми [5]. Загальна летальність від гострого панкреатиту коливається від 4,5 до $15 \%$, при деструктивному панкреатиті вона складає 24-60\%, а післяопераційна летальність сягає $70 \%$, і вони не мають тенденції до зниження $[1,5,12]$. Загалом результати лікування хворих на гострий панкреатит можна вважати задовільними, що пов'язано із недостатнім вивченням патогенезу даного захворювання $[2,6,8]$.

Фактично, біологічною суттю патогенетичного ланцюга гострого панкреатиту є ендотоксикоз, який супроводжується системними розладами мікроциркуляції, спричиняючи функціональну недостатність внутрішніх органів із розвитком поліорганної недостатності $[2,7]$.

Найважливішим регулятором системної гемодинаміки є саме ендотелій судин, який безпосеред-
Здоров'я організму залежить від здоров'я судин, а стан судин залежить від стану ендотелію.

ньо виділяє вазоактивні речовини і $€$ посередником у реалізації нервових, ендокринних та метаболічних механізмів регуляції стану судин [10]. Порушення функціонального стану ендотелію судин, або ендотеліальна дисфункція, проявляється відсутністю адекватної реакції судинної стінки у відповідь на подразники та регуляторні впливи. Дисфункція ендотелію, перш за все, характеризується погіршенням здатності судин розширюватися, що зумовлює зміну вазомоторного тонусу, міграцію лейкоцитів у стінку судини, ріст та проліферацію гладеньких м'язів, посилення впливу прокоагулянтних факторів, збільшення утворення вільних радикалів. Внаслідок цього можуть розвиватися тромбоз, запалення, вазоконстрикція, ремоделювання судин, а також поглиблюються запальні зміни тканин у місці запалення, провокується розвиток як місцевих, так і системних ускладнень $[9,10]$.

Серед методів діагностики функціонального стану ендотелію особливої уваги заслуговує лазер- 
на доплерівська флоуметрія. Цей метод цікавий тим, що лише він дає можливість оцінити активність ендотеліальних процесів у комплексі регуляторних впливів на дрібні судини мікроциркуляторного русла та виявити зміни активності ендотеліоцитів у відповідь на подразники та стресові чинники $[3,11]$. Лазерна доплерівська флоуметрія є доступним неінвазивним методом діагностики стану мікроциркуляторного русла і дає можливість оцінити зміни кровонаповнення кінцевих ланок системного кровотоку, вплив на них регуляторних факторів у динаміці захворювання [4]. Це дає можливість діагностувати порушення міроциркуляції, контролювати ефективність призначеної терапії та прогнозувати розвиток системних ускладнень.

Мета роботи: вивчити зміни активності ендотеліального компонента регуляції кровотоку в мікроциркуляторному руслі у хворих на гострий панкреатит у динаміці захворювання.

Матеріали і методи. В основу клінічного дослідження покладено аналіз комплексного обстеження 60 хворих на гострий панкреатит. Середній вік обстежених складав $(49,3 \pm 15,6)$ року. Серед них 38 (63\%) чоловіків та 22 (37\%) жінки. У 32 пацієнтів діагностовано набрякову форму панкреатиту, у 28 обстежених виявлено деструктивні форми захворювання. Контрольну групу склали 34 практично здорових особи. Усім обстеженим проведено лазерну доплерівську флоуметрію із оклюзійною пробою на одноканальному лазерному аналізаторі мікроциркуляції “ЛАКК-ІІ” (НПП “Лазма”, Росія) при довжині лазерного променя 0,8 мкм. Обстеження проводили в ділянці шкіри нижньої третини правого передпліччя в положенні хворого лежачи на спині [3]. Тривалість обстеження складала 8 хв: 3 хв реєструвався базальний кровотік та 5 хв складала оклюзійна проба із 2-хвилинним перетисненням плечової артерії тонометром та реєстрація показників реактивної гіперемії. Амплітудно-частотний спектр коливань кровотоку розраховували за допомогою вейвлет-аналізу до та після проведення оклюзійної проби. Результатом оклюзійної проби був показник резерву капілярного кровотоку (РКК). Аналізували зміну амплітуди ендотеліального компонента регуляції кровотоку за формулою:

$\Delta \mathrm{Ae}=(\mathrm{Ae}(\mathrm{OП)}-\mathrm{Ae}($ Б) $) \times 100 / \mathrm{Ae}($ Б),

де $\Delta \mathrm{Ae}$ - відсоток зміни амплітуди ендотеліальних коливань при проведенні оклюзійної проби, $\mathrm{Ae}$ (Б) - амплітуда ендотеліальних коливань кровотоку до проведення оклюзійної проби, Ае (ОП) амплітуда ендотеліальних коливань після проведення оклюзійної проби в момент реактивної гіперемії.
У групи обстежених відбирали тільки тих пацієнтів, тривалість захворювання у яких не перевищувала 24 год до госпіталізації в стаціонар. Обстеження проводили при прийнятті хворих, на третій день лікування та при виписуванні. Виконували консервативне лікування згідно з протоколами надання медичної допомоги, затвердженими МОЗ України.

Статистичну обробку отриманих результатів проводили за допомогою статистичних функцій програм "Microsoft Office Excel 2007" та "STATISTICA 8.0" на персональному комп'ютері, застосовуючи варіаційно-статистичний метод аналізу. Критичний рівень значимості при перевірці статистичних гіпотез у даному дослідженні приймали рівним 0,05 .

Результати досліджень та їх обговорення. Встановлено, що у здорових людей у стані спокою максимальна амплітуда ендотеліальних коливань у мікроциркуляторному руслі становить у середньому $0,31 \pm 0,12$. Після проведення оклюзійної проби в стадії реактивної гіперемії у здорових людей виявлено достовірне зростання амплітуди ендотеліальних коливань (рис. 1,2 ) більш як у 2 рази порівняно із базальним рівнем.

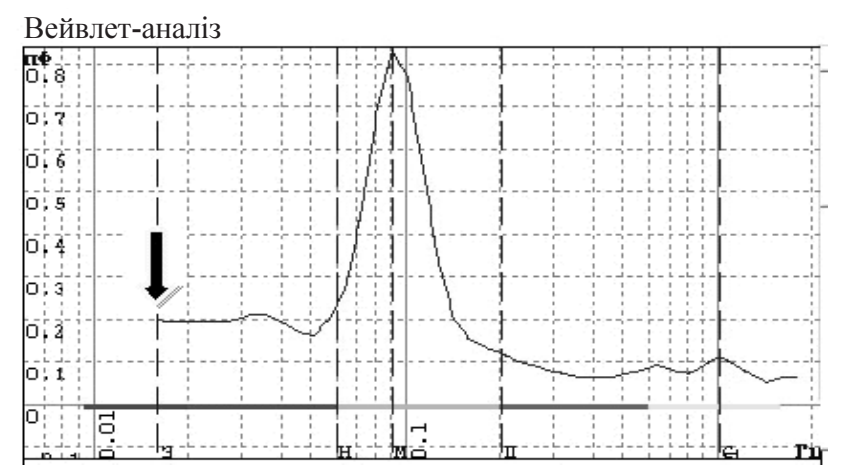

Рис. 1. Амплітуда ендотеліальних коливань у стані спокою при обстеженні здорового чоловіка (пацієнт Б., 26 років).

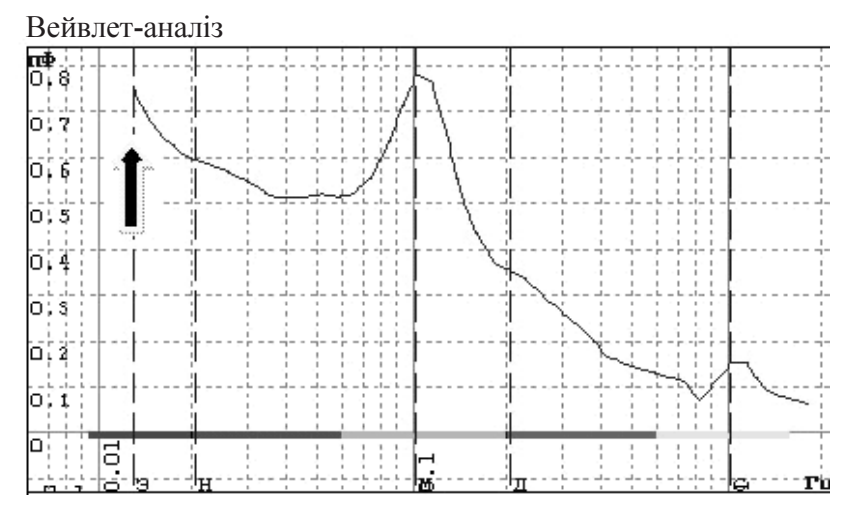

Рис. 2. Амплітуда ендотеліальних коливань після проведення оклюзійної проби при обстеженні здорового чоловіка (пацієнт Б., 26 років). 
У хворих на набрякову форму гострого панкреатиту базальна амплітуда ендотеліальних коливань майже не змінювалась впродовж захворювання (табл. 1) та достовірно не відрізнялась від показників контрольної групи (p>0,05). Отримані дані свідчать про відсутність системних змін у мікроциркуляторному руслі у хворих на набрякову форму панкреатиту на початку захворювання, або ж ці зміни $є$ компенсованими. Після тимчасової оклюзії у цій групі відмічається достовірно вище $(\mathrm{p}<0,05)$ зростання активності ендотеліального компонента регуляції кровотоку в перший день захворювання. Це зростання активності ендотелію майже не змінюється і на третю добу лікування набрякової форми гострого панкреатиту. При виписуванні цих хворих встановлено зниження амплітуди ендотеліальних коливань у стадії реактивної гіперемії, і ці показники наближаються до значень у групі здорових осіб $(\mathrm{p}>0,05)$.

При тяжкому перебігу панкреатиту базальний рівень ендотеліальних коливань на початку захворювання достовірно нижчий від контрольних показників $(\mathrm{p}<0,05)$. На третій день лікування цей показник має тенденцію до ще більшого зниження $(\mathrm{p}>0,05)$. Зниження активності ендотеліоцитів, ймовірно, пов'язане із зниженням кількості функціонуючих ендотеліоцитів внаслідок їх руйнування токсинами, інактивацією оксиду азоту вільними радикалами та іншими біологічними продуктами. При виписуванні хворих на панкреонекроз відмічається достовірне зростання базальної амплітуди ендотеліальних коливань порівняно 3 показниками на третій день захворювання. Очевидно, це зумовлено частковим відновленням функціональної активності ендотеліоцитів. Однак ці показники були достовірно нижчими порівняно зі значеннями у здоро- вих осіб $(\mathrm{p}<0,05)$. На початку захворювання амплітуда ендотеліальних коливань після проведення оклюзійної проби порівняно з групою здорових людей була вдвічі нижча, на третю добу - у тричі нижча, а при виписуванні хворих із стаціонару - дещо зростала, але була достовірно нижчою від показників здорових осіб.

При розрахунку відсотка зміни амплітуди ендотеліальних коливань при проведенні оклюзійної проби у хворих на набрякову форму гострого панкреатиту на початку захворювання виявлено підвищення $\Delta \mathrm{Ae}$ із поступовим зниженням показника в динаміці захворювання (рис. 3). Ці зміни пов'язані з активацією ендотеліоцитів i, відповідно, із зростанням їх функціональної активності у відповідь на подразник (гіпоксію).

У хворих на панкреонекроз на початку захворювання відмічається зниження $\Delta \mathrm{Ae}$ майже вдвічі порівняно з контролем (рис. 4). На третю добу захворювання активність ендотеліоцитів прогресивно знижувалась, що свідчить про посилення руйнування ендотеліоцитів та зниження їх функціональної активності. На час виписування зі стаціонару у хворих на панкреонекроз активність ендотеліоцитів зростала, про що свідчить достовірне $(\mathrm{p}<0,05)$ підвищення $\Delta \mathrm{Ae}$.

При розрахунку резерву капілярного кровотоку на початку захворювання встановлено два типи реагування: при набряковій формі панкреатиту різке зростання РКК, іноді до 1000-1500 од., та помірне чи незначне зростання РКК при панкреонекрозі (рис. 5, 6).

При набряковій формі панкреатиту оклюзійною пробою виявлено гіперреакцію ендотелію, що пов'язана із подразненням ендотеліальних клітин токсинами та ферментами. При панкреонекрозі реак-

Таблиця 1. Амплітуда ендотеліальних коливань у хворих на гострий панкреатит у динаміці

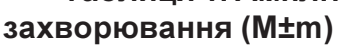

\begin{tabular}{|c|c|c|c|c|c|c|}
\hline \multirow{3}{*}{$\begin{array}{c}\text { Групи } \\
\text { обстежених }\end{array}$} & \multicolumn{6}{|c|}{ "Амплітуда ендотеліальних коливань } \\
\hline & \multicolumn{3}{|c|}{ до проведення оклюзійної проби } & \multicolumn{3}{|c|}{ після проведення оклюзійної проби } \\
\hline & $\begin{array}{c}\text { I доба } \\
\text { захворювання }\end{array}$ & $\begin{array}{c}\text { III доба } \\
\text { захворювання }\end{array}$ & $\begin{array}{l}\text { виписування } \\
\text { із стаціонару }\end{array}$ & $\begin{array}{c}\text { I доба } \\
\text { захворювання }\end{array}$ & $\begin{array}{c}\text { III доба } \\
\text { захворювання }\end{array}$ & $\begin{array}{l}\text { виписування } \\
\text { із стаціонару }\end{array}$ \\
\hline $\begin{array}{l}\text { Набрякова форма } \\
\text { панкреатиту } \\
(n=32)\end{array}$ & $0,33 \pm 0,09$ & $0,35 \pm 0,09$ & $0,33 \pm 0,06$ & $1,09 \pm 0,23 *$ & $1,12 \pm 0,19^{*}$ & $0,79 \pm 0,12^{\circ}$ \\
\hline $\begin{array}{l}\text { Панкреонекроз } \\
(\mathrm{n}=28)\end{array}$ & $0,22 \pm 0,06 * \#$ & $0,18 \pm 0,04 * \#$ & $0,25 \pm 0,05 * \#^{\circ}$ & $0,40 \pm 0,09 * \#$ & $0,24 \pm 0,04 * \#^{\circ}$ & $0,58 \pm 0,14 * \#^{\circ}$ \\
\hline $\begin{array}{l}\text { Здорові особи } \\
(\mathrm{n}=34)\end{array}$ & \multicolumn{3}{|c|}{$0,31 \pm 0,12$} & \multicolumn{3}{|c|}{$0,75 \pm 0,16$} \\
\hline
\end{tabular}

Примітки:

1) * - достовірність порівняно з контролем $(\mathrm{p}<0,05)$;

2) \# - достовірність між обстеженими групами $(\mathrm{p}<0,05)$;

$3)^{\circ}$ - достовірність у групах між показниками в динаміці лікування $(\mathrm{p}<0,05)$. 


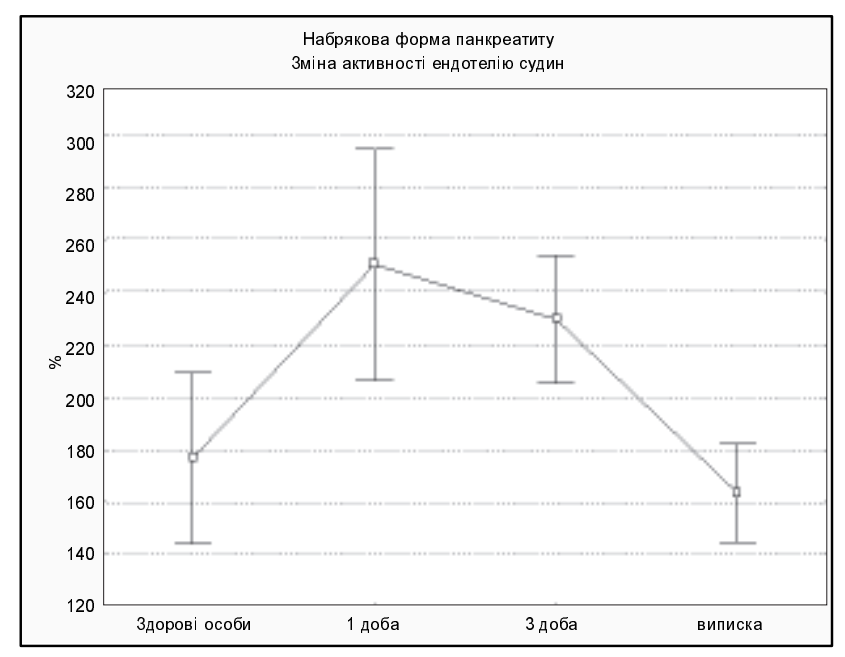

Рис. 3. Зміни $\Delta$ Ае у хворих на набрякову форму панкреатиту.

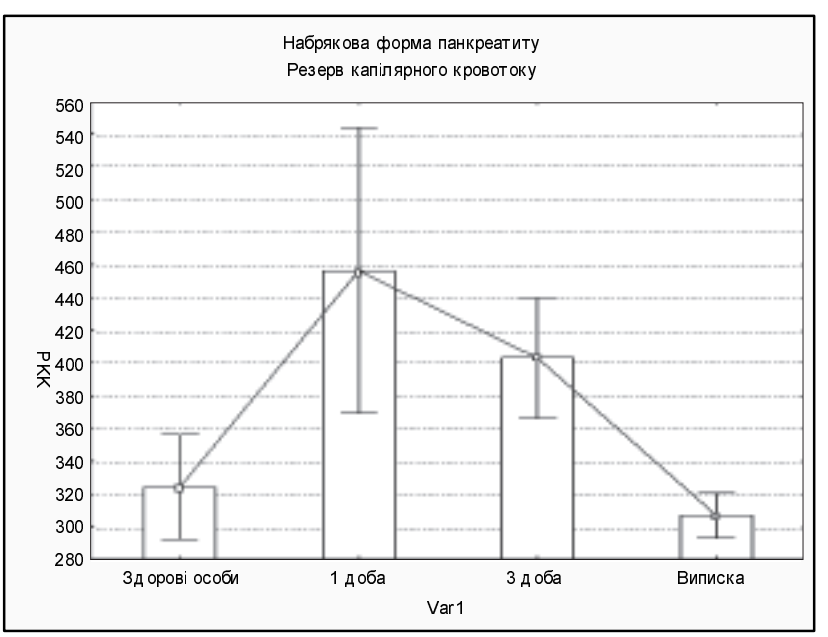

Рис. 5. Зміни РКК у хворих на набрякову форму панкреатиту.

ція наповнення мікроциркуляторного русла після цієї проби значно нижча, ніж у випадках набрякового панкреатиту. На нашу думку, це зумовлено тим, що при панкреонекрозі має місце руйнування ендотеліоцитів, внаслідок чого зменшується кількість активних ендотеліоцитів та підсилюються процеси зв’ язування молекул оксиду азоту продуктами перекисного окиснення ліпідів.

Рівень капілярного кровотоку при набряковій формі панкреатиту на початку захворювання різко підвищується, досягає максимуму на 3-й день захворювання та поступово знижується до показників здорових осіб на час виписування із стаціонару. При панкреонекрозі цей показник у динаміці знижується з перших днів захворювання і залишається зниженим до моменту виписування хворого.

Виявлені порушення регуляції судинного русла у хворих на гострий панкреатит є причиною погіршення кровонаповнення у системному мікроцир-

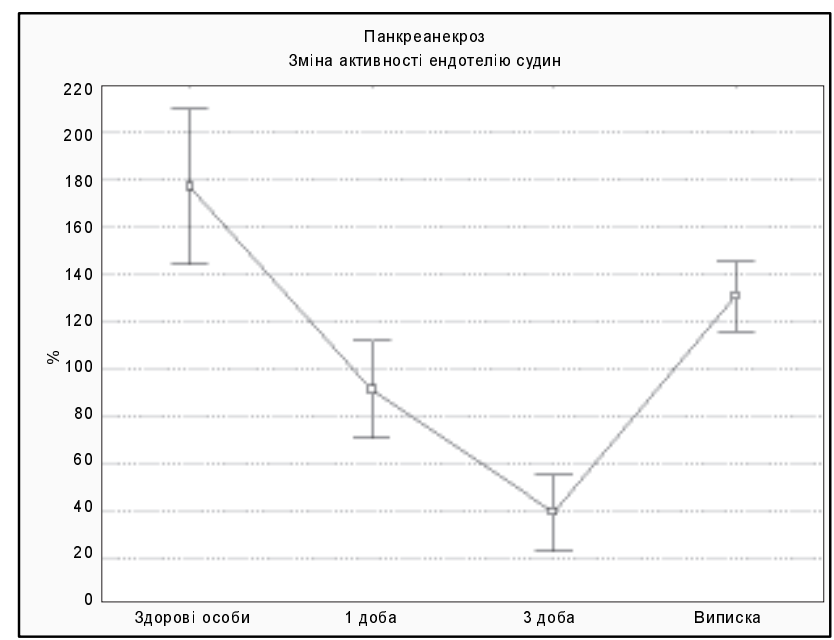

Рис. 4. Зміни $\Delta$ Ае у хворих на панкреонекроз.

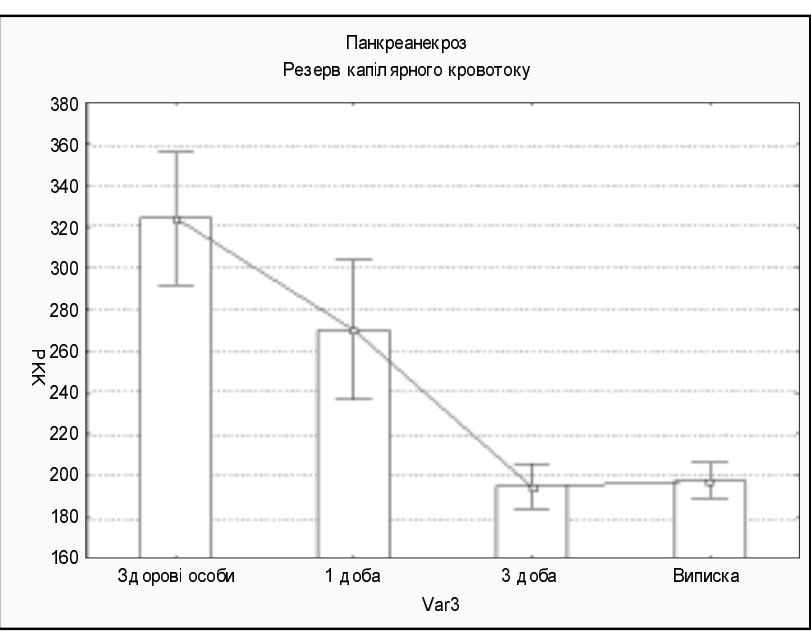

Рис. 6. Зміни РКК у хворих на панкреонекроз.

куляторному руслі, поглиблення гіпоксичних змін у підшлунковій залозі та інших органах, особливо при тяжкому перебігу захворювання.

Отже, ми встановили що у хворих на гострий панкреатит мають місце порушення функціонального стану ендотелію у мікроциркуляторному руслі. При набряковій формі панкреатиту відмічається різке зростання активності ендотеліоцитів. Цей стан варто розглядати як I стадію розвитку ендотеліальної дисфункції. У разі панкреонекрозу відмічається зниження резервного капілярного кровотоку, зумовлене низькою секреторною активністю ендотеліоцитів у регуляції судинного тонусу у відповідь на тимчасову ішемію (II стадія ендотеліальної дисфункції). У частини хворих із тяжким перебігом панкреатиту відсутня реакція на тимчасову оклюзію (РКК наближався до нуля) та різко знижений відсоток зміни амплітуди ендотеліальних коливань. Це вказує на відсутність реакції ендоте- 
лію на подразники (парез мікроциркуляції, або III стадія ендотеліальної дисфункції). На час виписування виявлено функціональну недостатність ендотелію судин, особливо у випадках тяжкого перебігу захворювання.

Висновок. Визначення стану мікроциркуляторного русла та реакції ендотелію у відповідь на тимчасову оклюзію методом лазерної доплерівської

\section{СПИСОК ЛІТЕРАТУРИ}

1. Багненко С. Ф. Острый панкреатит. Протоколы диагностики и лечения / С. Ф. Багненко, А. Д. Толстой // Анналы хирургической гепатологии. - 2006. - Т. 11, № 1. - С. 60-66.

2. Коновалов Е. П. Этиология и патогенез острого панкреатита (Обзор литературы) / Е. П. Коновалов // Анналы хирургической гепатологии. - 2000. - Т. 5, № 2. - С. 48-53.

3. Лазерная допплеровская флоуметрия микроциркуляции крови / под редакцией А. И. Крупаткина, В. В. Сидорова : руководство для врачей. - М. : ОАО "Изд-во "Медицина", 2005. $-256 \mathrm{c}$.

4. Лузин В. В. Лазерная допплеровская флоуметрия в оценке микроциркуляторных нарушений кишечной стенки при острой кишечной непроходимости в эксперименте / В. В. Лузин, П. М. Староконь // Медицинский альманах. - 2009. - № 3 (8). - С. $48-49$.

5. Толстой А. Д. Острый панкреатит: протоколы диагностики и лечения / А. Д. Толстой, С. Ф. Багненко, В. Б. Красногоров // Хирургия. - 2005. - № 7. - С. 19-23. флоуметрії дає можливість оцінити ступінь тяжкості гемодинамічних порушень у хворих на гострий панкреатит, прогнозувати розвиток ускладнень та контролювати ефективність лікування.

Перспективи подальших досліджень. Перспективним $€$ вивчення шляхів корекції ендотеліальної дисфункції у хворих на гострий панкреатит залежно від ступеня ураження ендотеліоцитів.

6. Шотт А. В. Эволюция методов лечения острого панкреатита / А. В. Шотт, С. И. Леонович, Г. Г. Кондратенко // Здравоохранение. - 2006. - № 12. - С. 40-46.

7. Cuthbertson C. M. Disturbances of the microcirculation in acute pancreatitis / C. M. Cuthbertson, C. Christophi // Br. J. Surg. - 2006. - № 93(5). - P. 518-530.

8. Granger J. Acute pancreatitis: models, markers, and mediators / J. Granger, D. Remick // Shock. - 2005. - № 24(1). - P. 45-51.

9. Menger M. D. Microcirculatory derangements in acute pancreatitis / M. D. Menger, T. Plusczyk, B. Vollmar // J Hepatobiliary Pancreat Surg. - 2001 - № 8(3) - P. 187-194.

10. Endothelial dysfunction / J. Nagy, B. Csiky, T. Kovacs, I. Wittmann // Orv. Hetil. - 2001. - Vol. 142(31). - P. 1667-1672. 11. Oberg P. A. Laser-Doppler flowmetry / P. A. Oberg // Crit. Rev. Biomed. Eng. - 1990. - № 18 (2). - P. 125-163.

12. Guidelines for the management of acute pancreatitis. Working Party report / J. Toouli, M. Brook-Smith, C. Bassi [et al.] // J. Gastroenterology and Hepatology. - 2002. - № 17. - P. 15-39. 